\title{
A CULTURA DA PAZ DE FRANCISCO DE ASSIS ATRAVÉS DA MEDIAÇÃO: UMA EXPERIÊNCIA JURÍDICA MEDIEVAL DE COMUNICAÇÃO NÃO VIOLENTA
}

\author{
THE PEACE CULTURE OF FRANCISCO DE ASSIS THROUGH IN MEDIATION: A \\ MEDIEVAL LAW EXPERIENCE WITH NONVIOLENT COMMUNICATION
}

\author{
NASCIMENTO, Douglas da ${ }^{1}$; SANTOS, Rosa Maria dos ${ }^{2}$ \\ Universidade São Francisco \\ douglas.veiga@usf.edu.br
}

\begin{abstract}
RESUMO. O presente artigo tem por escopo apresentar a figura pacificadora de Francisco de Assis, relacionado com a cultura da paz, através da mediação, como uma alternativa para a solução autocompositiva dos conflitos. Em um primeiro momento foi abordado o método utilizado para tal pesquisa, necessário para contextualização de Francisco de Assis na Idade Média, época em que vivera, para localizar o direito e a mediação no contexto da experiência jurídica medieval. Também foi realizada uma análise da cena narrada por São Boaventura sobre o encontro de Francisco de Assis com o Sultão Malik Al-Kamil, sintetizando as características que evidenciam as etapas que conduziram uma tentativa de mediação. Também é analisado o perfil de pacificador e de promotor da paz e algumas das estratégias e métodos da mediação que foram utilizadas por Francisco de Assis.
\end{abstract}

Palavras-chave: Cultura da Paz, Diálogo, São Francisco de Assis, Mediação, Pacificação.

ABSTRACT. This article aims to present the pacifying figure of Francisco de Assis, related to the culture of peace presented through mediation, as an alternative and autocompositive solution of conflicts. Firstly, the method used to address such research was necessary for the contextualization of Francis of Assisi in the Middle Ages in which he had lived and therefore to analyze his profile as peacemaker and peace promoter. Also the scene narrated by St. Bonaventure about the meeting of Francisco de Assis with Sultan Malik Al-Kamil was analyzed to incorporating the characteristics that show the steps that led to an attempt to mediate. And finally, it demonstrates the law and mediation in the middle ages through some of the strategies and methods of mediation that were used by Francisco de Assis.

Keywords: Culture of Peace, Dialogue, Saint Francis of Assisi, Mediation, Pacification.

\section{INTRODUÇÃO}

A Mediação é um importante instrumento para pacificação e resolução de conflitos na sociedade através da autocomposição, na qual um terceiro imparcial, o mediador, aplica determinadas técnicas de comunicação para que através delas possa melhorar o diálogo entre

\footnotetext{
${ }^{1}$ Doutorando em Direitos Humanos no Programa de Pós-Graduação em Direito da Universidade de São Paulo (USP). Mestre em Direito do Estado pelo Programa de Pós-Graduação em Direito da Universidade Federal do Paraná (2012). Bacharel em Direito pela Faculdade de Direito da Universidade Federal do Paraná (2010).

Professor da Faculdade de Direito da Universidade São Francisco (USF). Currículo:

$<$ http://lattes.cnpq.br/5174000235694660>

${ }^{2}$ Bacharelanda no curso de Direito da Universidade São Francisco.
} 


\section{http://ensaios.usf.edu.br/}

as partes e propiciar um ambiente favorável para que elas cheguem a um acordo. A mediação é uma técnica alternativa de resolução de conflitos, regulada pelo Novo Código de Processo Civil e pela Lei da Mediação (Lei n. 13.140/2015), que atualmente tem se consolidado e posta em destaque na política pública de solução de conflitos como alternativa à jurisdição estatal.

O termo "mediação" é empregado no presente artigo não com o objetivo de diferenciar os institutos da mediação, conciliação e negociação, como formas autocompositivas de resolução de conflitos, mas em abordar a mediação em função do campo específico de atuação do mediador que se demostra mais amplo, com uma abordagem psicológica e sociológica do conflito que faz dela o mecanismo mais eficiente para uma duradoura e efetiva pacificação das relações de conflito entre os indivíduos.

A título de distinção, a conciliação tem como objetivo alcançar o acordo, objetivando a extinção do processo e consequentemente da lide, sendo a resolução do mérito feita por transação, estipulando multas caso o acordo não seja efetivamente cumprido. Enquanto a mediação tem por finalidade maior descobrir os reais interesses e conflitos implícitos na lide, e assim solucionar tais conflitos de interesse, e que, consequentemente resultará em um acordo que atenda efetivamente os interesses das partes envolvidas. A figura do mediador ${ }^{3}$ no presente artigo está relacionada a Francisco de Assis, que atua no campo específico da pacificação social e da solução de conflitos, muitas vezes incompreensíveis e cheios de resquícios e relações pré-existente entre as partes, através de técnicas de comunicação.

O presente artigo está voltado para o campo da história do direito na Idade Média, tendo como enfoque as referências a Francisco de Assis, como um dos personagens da história medieval, que nos permite ter uma percepção da mediação ao longo da trajetória de sua vida e de suas crenças, com intensidade e ao mesmo tempo singeleza, em seu modo de vida rígido e, por tal motivo, buscou nas circunstâncias mais miseráveis que a vida lhe colocava um sentido potencial para transformar as vidas de outras pessoas, compreendendo os problemas e conflitos do próximo.

O carisma vivido por Francisco de Assis e seu modo de vida e testemunho inspiram pessoas a viverem os mesmos valores e princípios. Porém, o presente artigo tem como finalidade identificar determinadas metodologias utilizadas por Francisco de Assis para formação de seu perfil pacificador e promotor da paz social através do diálogo verbal e não verbal e da comunicação não violenta.

Para melhor compreensão do processo de conversão de Francisco de Assis e os paradigmas da igreja medieval por ele quebrado, é preciso compreender o contexto político, social e religioso no qual se deu a juventude de Francisco de Assis, pois sem dúvida Assis ${ }^{4}$ foi o cenário onde de fato Francisco mais se deixou conhecer.

\section{BIOGRAFIA HISTÓRICA}

A Biografia histórica configura-se como uma pesquisa histórica, que contextualiza determinada personalidade assim como as influências de sua época, inserindo na situação vivida pelo personagem fatos e narrativas a ele vinculados. A terceira geração da escola de Annales impulsionou a produção destes artigos entre os historiadores, pois através de uma

\footnotetext{
3 Mediador aquele que serve de intermediário. Do latim mediátor, óris (mediador, medianeiro). Etimologicamente, esta palavra tem origem no latim Concilium que indicava um conjunto de pessoas em reunião. No termo jurídico: que atua como facilitador entre pessoas, que estão em contenda ou têm pontos de vista divergentes acerca de determinada questão.

${ }^{4}$ Assis em italiano: Assisi; anteriormente Asisium, em latim, é uma cidade na região da Úmbria, na Itália.
} 


\title{
http://ensaios.usf.edu.br/
}

biografia histórica é possível ter uma visão diferente sobre o personagem. Marc Bloch contribui significativamente para esta nova visão da história, tomando conhecimento de assuntos da historiografia contemporânea e preenchendo de certa forma lacunas a respeito de fatos relevantes e contextualizações indispensáveis. Tal contextualização se faz necessário no presente artigo, pois possibilitará melhor compreensão, acompanhando a modificação do período medieval.

Segundo Peter Burke ${ }^{5}$, em sua escrita a respeito da invenção da biografia e o individualismo renascentista, é demostrado a presença das biografias ao longo da história de alguns personagens importantes, dentre eles Francisco de Assis:

\begin{abstract}
Afinal de contas, podemos encontrar biografia, se não, como já foi dito, "em todas as épocas e países", ao menos em muitas culturas e períodos. Entre as biografias medievais mais citadas nesse contexto estão as de Luís VI por Suger, de Luís IX por Joinville e de Luís XI por Commynes, as vidas de Guilherme Marechal e de Bayard, anônimas, e, mais ao norte, as vidas dos reis nórdicos, escritas na Islândia no século XIII por Snorri Sturluson. Podemos acrescentar as vidas do Rei Alfredo por Asser e de Santo Anselmo por Eadmer, e as de São Tomás de Aquino e São Francisco (BURKE, 1997, p. 83).
\end{abstract}

A Biografia é uma das formas mais antigas da história, mesmo assim acabou não sendo muito utilizada por um período, pois era considerada ultrapassada até meados do século $\mathrm{XX}$, porém seu surgimento deu-se por volta do século $\mathrm{X}$ a.C. Por não haver escritos em tal período, os registros eram demostrados através de pinturas em vasos, assim como na atuação de dramas, comédias e tragédias. No período medieval, a biografia é empregada principalmente para relatar a vida dos santos, deste feito São Francisco se faz exemplo de tal pesquisa.

No presente caso, tem-se como base a análise medieval através do historiador Jacques Le Goff ${ }^{6}$, que se preocupa em introduzir o gênero biográfico na história atual, acendendo caminhos para que a vida de Francisco de Assis fosse compreendida. É característico de Le Goff usar como método de estudo a análise cultural e a relação do personagem com a civilização da época abordada.

Sendo historiador compilava estudos sobre a Idade Média, e sua empatia pela pessoa de Francisco de Assis o motivou a estudá-lo mais profundamente, como relata em sua obra dedicada a Francisco de Assis:

Há meio século, quando comecei a me interessar pela Idade Média, sou duplamente interessado pela personagem de São Francisco de Assis. Primeiro, pelo personagem histórico que no coração da virada decisiva do século XII para o XIII em que nasceu uma Idade Média moderna e dinâmica, sacudiu a religião, a civilização e a sociedade (LE GOFF, 2001, p. 11).

\footnotetext{
${ }^{5}$ Em sua análise dos usos da biografia no Renascimento europeu, Peter Burke (1997, pp. 83-98) procurou analisar de que maneira a ideia de indivíduo teria sido pensada no período. Para ele, não seria a especificidade do indivíduo que prevaleceria nas narrativas, mas sim sua relação com a coletividade. É mais na coletividade que os indivíduos apareceriam. Apesar de construir um painel sobre a época do reinado de Luís XIV, o rei sol, seu objetivo foi justamente o de apreender de que maneira o rei, indivíduo, foi fabricado pelas coletividades, e essa imagem perdurou para a posteridade, principalmente em função da manutenção da "memória coletiva" e dos "lugares de memória" (BURKE, 1994).

${ }^{6}$ Jacques Le Goff (Toulon, 1 de janeiro de 1924 - Paris, 1 de abril de 2014) foi um historiador francês especialista em Idade Média. Autor de dezenas de livros e trabalhos, era membro da Escola dos Annales, empregou-se em antropologia histórica do ocidente medieval.
} 


\section{http://ensaios.usf.edu.br/}

Não se pode passar despercebido um fato importante a respeito dos biógrafos de São Francisco de Assis, a chamada "fogueira santa", em que nos primeiros séculos do Franciscanismo centenas de manuscritos foram queimados. Após a publicação dos escritos de São Boaventura ${ }^{7}$ que possuía o título de Teólogo, fatos e eventos que contextualizavam mais profundamente a vida de Francisco de Assis foram queimados em todos os mosteiros Franciscanos, cada frade possuía de forma compilada, uma biografia do fundador, pois o mesmo estava inserido na liturgia da igreja. Graças aos desvios de algumas obras, hoje se tem a junção das Fontes Franciscanas, sendo resquícios que escaparam da grande fogueira.

Para não cairmos no desacerto de uma visão unidimensional, é necessária uma pesquisa entre os acontecimentos mais relevantes que influenciaram fortemente a vida de Francisco de Assis, assim como o grupo o qual fazia parte, ou seja, as características da elite a que pertencera. A partir da contextualização se compreende a problematização e a leitura de diversas obras de diversos autores e os apontamentos divergentes entre esses oito séculos que transcendem sua época, chegando à contextualização do mesmo nos dias atuais, mais profundamente dentro do panorama da mediação.

\section{O DIREITO E A MEDIAÇÃO NA IDADE MÉDIA}

Se basear na origem de algo é sempre abstruso, ultrapassa os limites de ilustrar fidedignamente a cosmo visão do direito na Idade Média, mas é indispensável contextualizar as fontes do direito da época e as diferentes experiências jurídicas preservadas nos fragmentos e nas fontes históricas. A mediação como instituto jurídico aparece muito antes da mediação na modernidade. A bíblia, por exemplo, já recomendava a atitude de se conciliar, e somente se não fosse possível, o assunto seria "julgado" pelo juiz.

Como relata os livros de Mateus e Lucas:

Assume logo uma atitude conciliadora com o teu adversário, enquanto estás com ele no caminho, para não acontecer que o adversário te entregue ao juiz e o juiz ao guarda e, assim, sejas lançado na prisão. Em verdade te digo: dali não sairás, enquanto não pagares o último centavo (Mateus, 5:25-26; Lucas, 12:57-58).

Durante o século XIII, o direito assim como a Igreja se mostra descentralizado, ou seja, não estatal, não legislado e sem que qualquer instituição possuísse o monopólio do direito e da jurisdição. Seu surgimento se dá na tentativa de solucionar problemas cotidianos, a sociedade vê-se confrontada pelas necessidades que surgem. Assim quando uma norma se

\footnotetext{
7 São Boaventura (1221-1274): bispo franciscano, filósofo, confessor e doutor da Igreja. Foi uma das mais poderosas inteligências de seu tempo e de toda a história da Igreja. Boaventura nasceu no centro da Itália em 1218, e ao ficar muito doente recebeu a cura por meio de uma oração feita por São Francisco de Assis, que percebendo a graça tomou-o nos braços e disse: “Ó, boa ventura!". Entrou na Ordem Franciscana e, pela mortificação dos sentidos e muita oração, exerceu sua vocação franciscana e sacerdócio na santidade. Discípulo de Alexandre de Hales, era amigo e companheiro de lutas do dominicano Tomás de Aquino. Tiveram ambos carreiras paralelas, juntos combateram os erros de doutores de Paris inimigos das Ordens mendicantes. Falece relativamente jovem aos 56 anos. Também conseguiu superar a disputa interna de seus pares a respeito do voto de pobreza. Em 1273, foi nomeado cardeal-bispo de Albano e, no segundo Concílio de Lyon, desempenhou papel fundamental na reconciliação entre o clero secular e as ordens mendicantes. Foi nesse encontro que São Boaventura morreu, em 15 de julho de 1274. São Boaventura era um homem de muita ciência, porém, de maior humildade e conhecimento de Deus. Foi declarado doutor da igreja e canonizado em 1482.
} 


\section{http://ensaios.usf.edu.br/}

demonstra inadequada, pela necessidade outras normas vão surgindo naturalmente pelo trabalho dos juristas e na experiência jurídica popular. (ZEHR, 2008, p.118).

Howard Zehr em seu Livro "Trocando as Lentes", elucida tal necessidade que surgia à medida que os delitos eram cometidos:

No final da Idade Média começaram a reclamar o direito de fazer novas leis e derrogar as antigas. Códigos legislativos formais, escritos, que incorporavam novos princípios começaram a substituir os costumes. Nos séculos XVIII e XIX um corpo legislativo especial havia sido criado para tratar de certos danos e disputas chamados crimes (ZEHR, 2008, p.103).

Assim, sobretudo no século XIII, surge uma jovem relação com o direito, sendo denominado de "direito comum". Deste modo, o direito comum não dependia basicamente do Estado, sua aplicação estava sujeita às circunstâncias que eram apresentadas, estando presente em diversas instituições, um micro poder, é pluralista e não há uma fonte única centralizadora.

Segundo o historiador Paolo Grossi, tal interpretação poderia variar de acordo com os sujeitos que o interpretavam: como o príncipe, o comunal $^{8}$, o juiz ou o mestre. Há multiplicidade de sujeitos, portanto o direito medieval origina-se de diversas fontes não estando completamente vinculado ao poder político. Tem interpretação pessoal, ou de determinado grupo, não há uma fórmula concreta, deriva da atividade do intérprete a função de mediar os fatos e as normas. Porém, havia limites impostos pela igreja, pois, o direito canônico tomava como princípio a diferença efetiva entre as pessoas. Assim como no direito civil, no qual funcionava da mesma maneira, alterava conforme o caso e situações das pessoas, para se chegar à realização da justiça. (GROSSI, 2014).

Howard Zehr assume que o desenvolvimento da lei canônica influencia diretamente a aplicação do direito em tal época:

Paulatinamente, surgiram vários centros de poder que competiam entre si, cada qual alegando certa autoridade. Problemas de disciplina interna também afligiram a Igreja. Portanto, uma das principais preocupações do papado durante o período medieval era consolidar sua autoridade dentro dela. Ao mesmo tempo, o papado estava envolvido numa luta para ter igual autoridade, ou mais autoridade que as autoridades "seculares" ou políticas. Mas várias autoridades seculares centralizadoras começavam a emergir nessa época, e apresentavam necessidades similares. Também queriam consolidar seu poder dentro de suas próprias esferas, buscando modos de subordinar outros centros de poder, inclusive a Igreja. Tanto as autoridades religiosas como as seculares, portanto, buscavam novos argumentos e recursos que os ajudassem a consolidar o seu poder. As leis do Império Romano já extinto ofereceram o instrumento ideal, primeiro para a Igreja e depois para o Estado. Durante a era republicana da história romana o crime era basicamente uma questão privada da comunidade, sendo que o Estado tinha papel limitado. Com a ascensão do Império, contudo, desenvolveu-se uma tradição jurídica que reconheceu e expandiu o papel daquele na criação das leis e na administração da justiça (ZEHR, 2008, p.106).

\footnotetext{
${ }^{8}$ Eleitos pelos cidadãos, deputados ou pelo povo, tinham o poder executivo, julgavam matérias como civil e penal, o número variava. Em Assis os cônsules só apareceram entra 1198 e 1212, porém após esse período foram perdendo sua estima, no começo eram personagens extraordinários, com poderes ditatoriais.
} 


\section{http://ensaios.usf.edu.br/}

No campo da mediação, o Papa, assim como os bispos empregam a mediação para solucionar conflitos que lhes cabiam resolver, sendo utilizada durante a Idade Média e por parte do renascimento. No sistema feudal, a mediação encontra um cenário favorável, principalmente dentro da própria igreja ou no interior das comunas.

Com a independência das cidades do norte da Itália e sua certa "autonomia" o comércio em expansão favorece o uso da Arbitragem entre comerciantes que escolhiam seus árbitros:

A mediação, desde antiguidade, trazia ideia de interesses na busca de resolver alguma contrariedade entre os homens, que buscavam a paz e harmonia nas relações. Apesar de maior incidência na cultura chinesa, japonesa e africana, a mediação de conflitos fez-se presente em diversas sociedades ao longo dos séculos. Sua evolução trouxe, nos séculos XIX e XX, a possibilidade de solucionar disputas comerciais e trabalhistas como um meio alternativo célere e eficiente (MIRANDA, 2012, p. 14).

Os espaços de mediação surgem de uma necessidade da própria organização social e coletiva, pois aos poucos se tornam relações complexas. O lugar dessa mediação é híbrido, assim como a natureza jurídica da mediação visto que surge da necessidade de um espaço para as ações coletivas. Na Idade Média, especificamente, o local onde ocorriam as mediações era as praças, mais que um espaço geográfico, as praças eram o coração das cidades da europa.

Frei Celso Márcio Teixeira nos situa a respeito da importância da praça, sendo o local onde a população se reunia: "A praça reunia tambem o povo para o divertimento: jogos dos cavaleiros, encenações, autos sacros, espetaculos dos joculatores: Pode-se dizer que a praça constituia o eixo em torno do qual girava toda a vida da população citadina (Teixeira, 2007, p.22)".

As praças na Idade Média reuniam a oscilação da população, é o local onde o Estado (Papal ou Imperial) manifesta ações governamentais, realizando cerimônias, anunciando leis ou punindo os infratores. Le Goff define a praça pública medieval como um espaço social, centro de atração para o qual se voltavam as preocupações do urbanismo. Por conta do mercado e da feira, o mundo camponês penetra na cidade. Lá encontra a cultura mercantil, a cultura eclesiástica e mesmo a cultura cavaleiresca. Mesmo fora das festas, na vida cotidiana, o encontro se realiza (LE GOFF, 1992, p. 207).

\section{A FIGURA DE FRANCISCO DE ASSIS NA IDADE MÉDIA}

O Filho de Pedro Bernardone e Senhora Picca, nascera em fins do ano de 1182 na cidade de Assis, na Itália região da Úmbria, sendo batizado com o nome de João Batista. Bernardone comerciante fascinado por riquezas tinha como maior atrativo os negócios, buscando sempre o lucro, enquanto Picca era uma boa e piedosa senhora. Pedro tinha grande empatia pela França, viajava com frequência à França para comerciar, inclusive no momento do nascimento de Francisco não se encontrava em Assis, quando regressou decidiu dar um novo nome ao filho, Francisco em homenagem à França. Visava ter em Francisco um auxiliar poderoso e sucessor brilhante, então impôs a ele o estudo francês, rapidamente escrevia e falava como um francês, tronando-se o orgulho de seu pai.

Francisco tinha como paixão o dinheiro, amava o luxo e a elegância. Porém mesmo levando uma vida leviana, quando se referia ao amor de Deus ele estremecia, nunca se 


\title{
http://ensaios.usf.edu.br/
}

esquecera das palavras do evangelho que sua mãe o ensinará que diz: "Quem se apieda do pobre, empresta ao Senhor, que lhe restituirá o benefício"9.

Cresceu em um cenário político em que diversas cidades da Itália se desenvolviam para uma autonomia, mesmo ainda sob autoridade imperial e forte influência da autoridade pontifícia. Perusa e Assis viviam uma intensa rivalidade, os moços de uma e outra cidade, sempre estavam em batalha, sendo muitas vezes um combate mortífero, em um desses encontros Francisco e seus amigos foram capturados como prisioneiros, conduzidos à Perusa sofriam amargas provações, mas Francisco não se abalava e ainda consolava seus companheiros.

Raffaele Pazzelli no livro São Francisco e a Ordem Terceira conta de forma mais detalha o conflito entre Perusa e Assis:

\begin{abstract}
As razões atávicas para Assis ser "imperial" baseavam-se no fato que Perusa, a eterna inimiga era "papal". Só uma síntese histórica de situações seculares e de eventos especiais explica essa inimizade que estava no ar que se respirava, e era herdada de geração em geração. Francisco não foi exceção. Perusa e Assis, embora tão vizinhas geograficamente, pertenciam a civilizações diferentes, divididas pelo Rio Tibre. Esse curso de água, como tinha dividido nos tempos de Roma a Túscia da Úmbria, tinha mantido dividida na Idade média a parte ocupada pelos Bizantinos, com Perusa, da parte ocupada pelos Longobardos: o ducado de Spoleto - que compreendia também Assis (PAZZELII, 2009, p. 106).
\end{abstract}

Ao regressar a Assis, Francisco cai em extrema enfermidade, chegando à beira da morte, Após se restabelecer se sentia um novo Francisco diferente do que fora antes, as paixões que tinha anteriormente, agora não o faziam mais sentido, as considerava como ilusões e vaidades. Os amigos o convidavam a sua vida de luxo e de banquetes, porém ao contrário disso Francisco crescia em temência e doava muito mais aos pobres. Não se via mais Francisco entre os amigos, quase não ajudava mais seu pai nos negócios, e com frequência costumava se retirar em uma gruta próxima a Assis, onde passava horas a fio na companhia de Deus. Francisco, desta form, a optara pela pobreza, a humildade, e a caridade com os pobres, doentes e leprosos. Os Amigos o questionavam a respeito de com quem Francisco se casaria, mas ele já havia escolhido sua esposa, escolhera casar com a pobreza e tomá-la como esposa.

Dificilmente conseguir-se-á destacar o que de fato influenciou a "conversão" de Francisco de Assis, a derrota em Collestrada certamente foi fundamental para tal. Os cárceres de fato eram sub-humanos e os prisioneiros ficavam em situações precárias. As vantagens e o dinheiro não eram mais úteis naquele momento, as belas roupas, as amizades e os baquetes não estavam mais em seu alcance, e não lhe podiam trazer alento nenhum. Não se sabe ao certo como se deu a sua mudança de comportamento, somente sabe-se que durou em média de um ano sua prisão.

Le Goff ao relatar a conversão de Francisco de Assis considera confusa e prolongada, mas destaca a importância para se entender o Francisco que nascera e que juntamente com ele nascia a espiritualidade franciscana:

Não bastaria reconhecer que é penosamente que se analisa um fenômeno de conversão e que o mais importante para o historiador é restringir-se aos temas, aos episodio que marcaram as etapas e deles extrair a importância histórica? Impressiona logo o fato de que, apesar do caráter de iluminação repentina, da brusca

\footnotetext{
${ }^{9}$ Provérbios, 19:17.
} 


\section{http://ensaios.usf.edu.br/}

alteração que sempre reveste uma conversão numa narrativa biográfica, a de São Francisco, segundo São Tomás, se entenda por quatro ou cinco anos e siga um itinerário, caminhe através de muitos episódios (LE GOFF, 2009, p.62-63).

Ao continuar a transcorrer o cenário histórico da conversão de Francisco, não se pode desconhecer a situação social de Assis, que ainda na juventude de Francisco passava por grandes mudanças nas classes sociais. Por séculos na alta Idade Média, a situação era a divisão somente entre nobres e plebeus, posteriormente se dá o surgimento dos burgueses, e consequentemente o aparecimento das outras classes. Nas cidades centrais da Itália, assim como em Assis a divisão se dava entre os nobres tradicionais e os emergentes de cidades, feudatários ${ }^{10}$, os juízes e comerciantes ricos.

No mesmo livro de Raffaele Pazzelli, podemos imaginar as características da nova classe que surgia:

De fato, fazia tempo que havia uma força nova nas cidades das italianas, a dos comerciantes que afirmavam sua crescente importância, destinada a passar bem depressa a supremacia, baseada no dinheiro, ocupadíssima em compras e vendas, ciumenta, vaidosa, facciosa, que rivalizava em importância com o feudatário. $\mathrm{Na}$ ocasião eram dois poderes em luta, dois orgulhos que se roçam estridentemente (PAZZELII, 2009, p. 111).

Os recém-chegados esbanjavam riquezas, invejando os feudatários já estabelecidos, entre estes alguns se tornavam grandes comerciantes. Começa também a grande concorrência pelo domínio do comércio e a ambição pelo lucro. Nesse ambiente Francisco cresceu, tendo seu Pai, dentre os grandes mercadores e mais ricos de Assis, Bernardone, grande interesse no lucro que a guerra poderia lhe trazer, incentivando o sonho cavaleiresco do filho. Pois a pessoa valia não pelo fato de ser pessoa, mas pelo título que portava ou pelo trabalho que confeccionasse.

Assim entraremos no ponto em que melhor entenderemos quem era Francisco de Assis e os elementos que perdurará até mesmo após sua conversão, o "Elemento Cavaleiresco", presente em sua criação foi profundamente incutido em sua personalidade, sua maneira cortês, aliada à elegância, à fineza e à coragem. Tal ensinamento estava presente na formação da classe nobre e que tinha mais condições financeiras. Francisco de Assis mesmo não sendo nobre de nascimento teve sempre por companhia os filhos dos nobres e consequentemente tinha os mesmos ideais da cavalaria, que posteriormente influenciou fortemente a fraternidade franciscana. Os nobres iam a cavalo, guerreava-se com lanças e espadas, vestidos em armaduras de metal. Na Legenda dos Três Companheiro no capitulo XI relata que Francisco manda fazer as roupas mais ricas e elegantes para usar na batalha. O Cavaleiro era considerado herói, virtuoso e defensor da fé e dos pobres:

O cavaleiro era pintado como herói, uma pessoa de virtudes. Para ser cavaleiro, o jovem devia ser profundamente religioso, fiel, de bons sentimentos e virtudes, corajoso, austero e sóbrio. Sua investidura era feita na igreja, onde o bispo benzia a espada e lhe entregava para que defendesse a fé e os pobres. Como sinal de sua prontidão, durante a leitura do evangelho da missa, o cavaleiro mantinha erguida a

\footnotetext{
10 Naquela época, vivia-se na Europa um sistema social, político econômico denominado Feudalismo. No Feudalismo, os proprietários de grandes partes de terras, era também proprietários das pessoas que nelas moravam e trabalhavam. Esses senhores "nobres" moravam em castelos e viviam do que seus "servos" produziam.
} 


\section{http://ensaios.usf.edu.br/}

espada desembainhada, consciente que a cavalaria era a força armada a serviço da verdade (PINTARELLI, 1997, p.8-9).

O cristianismo era a religião predominante na região da Europa, porém havia resquícios de crenças pagãs como a bruxaria e a prática de magia, havendo uma mistura de superstições. Na política, uma elite mandava, e o pobre em geral era uma pessoa sem importância, sendo mero instrumento para a salvação do rico. Francisco em contraponto introduz uma nova visão sobre o pobre, sendo um pobre que passa a ser valorizado em si. A proposta de Francisco materializava a prática social a partir de uma nova forma de piedade, e ocupa pouco a pouco um lugar respeitável na Igreja Medieval.

\section{A CULTURA DA PAZ EM FRANCISCO DE ASSIS}

Francisco de Assis é conhecido por todo o mundo, em diversas crenças, diversos povos, diversas línguas, um personagem muito conhecido e admirado, mesmo por aqueles que não comungam de sua fé, pelas suas realizações, mesmo por aqueles que não toleravam a fé cristã. É impossível dizer algo especifico que possa caracterizá-lo, entretanto no Primeiro Livro de São Tomás de Celano ${ }^{11}$, Primeira Vida de São Francisco, é possível ao menos imaginar seu aspecto físico e moral pelas seguintes características:

Quão belo e esplêndido, quão glorioso se manifestava na inocência de vida, na simplicidade das palavras, na pureza de coração, no amor a Deus, na caridade fraterna, na obediência ardorosa, no serviço cordial, no aspecto angelical. Delicado nas maneiras, tranquilo por natureza, afável na palavra, muito convincente na exortação, fidelíssimo ao que era confiado, previdente na deliberação, eficiente no trabalho, simpático em tudo. Sereno no pensar inteligente, brando no ânimo, sóbrio no espírito, absorvido pela contemplação, assíduo na oração e fervoroso em tudo. Firme no propósito, estável na virtude, perseverante na graça e sempre o mesmo em tudo. Veloz para perdoar, lento para irar-se, inteligência livre, memória brilhante, sutil em discutir, circunspecto em escolher e simples em tudo. Rigoroso para consigo mesmo, compassivo para com os outros, discreto para com todos[...]Homem eloquentíssimo, fisionomia alegre, aspecto benigno, imune a preguiça, desprovido de arrogância[...]E porque era muito humilde, mostrava toda mansidão para com todos os homens, conformando-se de maneira saudável aos costumes de todos (CELANO, s.a, p. 83)

Mais como evidenciar que de fato Francisco era capaz de resolver e pacificar conflitos? A resposta é encontrada dentro de sua própria vida, mais precisamente em fatos históricos que transcenderam décadas; foi capaz de se dirigir com uma postura humilde ao Sultão Malik Al-Kamil ${ }^{12}$, conhecido por premiar aqueles que matavam cristãos. Além de

\footnotetext{
${ }^{11}$ Tomás de Celano (1200-1265): frade católico medieval da Ordem dos Franciscanos, um poeta e também um escritor, sendo autor de três obras de cariz biográfico sobre São Francisco de Assis. Em 1221, Tomás foi enviado para o Sacro Império Romano-Germânico com Caesarius de Speyer para promover ali a Ordem dos Franciscanos. Em 1223, ele foi nomeado para o cargo de Custos Unicus da Ordem na província da Renânia. Depois voltou à Itália, onde se retirou o resto de sua vida. Em 1260, ele foi liquidado no seu último posto como diretor espiritual do convento das Clarissas em Tagliacozzo, onde morreu entre 1260 e 1270.

${ }^{12}$ O Sultão Malik Al-Kāmil, nasceu em 1180 e viveu até 1238, a partir de 1218 governou o Egito, a Palestina e a Síria durante a Quinta e Sexta Cruzadas. Em sua ascensão ao sultanato, Al-Kāmil contratou os exércitos da Quinta Cruzada e eventualmente negociou sua retirada do Egito em 1221. Durante este conflito teve um diálogo com São Francisco de Assis, que desejava convertê-lo ao cristianismo. Em 1229 Al-Kāmil cedeu Jerusalém e outras cidades palestinas ao II, líder da Sexta Cruzada.
} 


\title{
http://ensaios.usf.edu.br/
}

viver a paz, Francisco transmitia a paz a todos que cruzavam seu caminho. Há um pergaminho, entregue por Francisco ao Frei Leão, que contém o texto de uma bênção: "O Senhor te abençoe e te guarde, O Senhor Mostre a ti o seu rosto e tenha misericórdia de ti. O Senhor Volte para ti o seu olhar e te dê a paz". Tal escrito de São Francisco corresponde à benção de Aarão do livro dos Números. ${ }^{13}$

Nas fontes Franciscanas, mais especificamente na Regra Bulada, Francisco recomenda aos seus confrades a paz de espirito e como devem ser portadores da paz:

\begin{abstract}
"Aconselho, admoesto e exorto a meus Irmãos em Nosso Senhor Jesus Cristo que, ao irem pelo mundo, não discutam, nem porfiem com palavras, nem façam juízo de outrem, mas sejam mansos, pacíficos, modestos, afáveis e humildes, tratando a todos[...]. Ao entrarem em qualquer casa, digam antes: Paz a esta casa!" (RB, III)
\end{abstract}

Francisco sempre foi um agente da paz, tal inspiração é notória e advinha daquele que decidiu seguir, tendo como base o evangelho, ou seja, decidiu viver aquilo que Jesus seu mestre vivia. Jesus de Nazaré não respondeu com violência àqueles que o tratavam com violência, a ponto de dizer a um de seus discípulos que guardasse a espada na bainha ${ }^{14}$ quando estava prestes a ser preso e violentado, ao contrário agia com mansidão, utilizando a linguagem da reconciliação e da clemência. Deste modo, o perfil pacificador de Francisco se deu por levar a Paz Daquele que lhe trazia a Paz, o desejo de paz de Francisco não era meramente uma saudação, mas um verdadeiro programa de vida, como portador da paz e do bem, procura restabelecer a paz e o bem onde quer que vá. Mesmo vivendo em um panorama de guerra como vimos nos tópicos anteriores, Francisco jamais teve qualquer atitude violenta ao contrário era capaz de transformar cenários e conflitos em oásis de paz.

\section{PASSOS DE FRANCISCO DE ASSIS PARA ALCANÇAR UM DIÁLOGO DE PAZ}

Aprendemos com Francisco que diante de possíveis conflitos, temos que ser pessoas de paz, de diálogos, dispostos a ir ao encontro das soluções. A cultura da Paz não estava presente através de um comportamento esporádico na pessoa de Francisco, mas estava em seu ser, vivia a paz e transcendia a paz. Um exemplo disso foi a história narrada nas Fontes Franciscanas, que revela a pedagogia da paz de Francisco, é a parábola ou alegoria do "Lobo de Gubbio", contada em Fioretti XXI que se passou na cidade de Gúbio, na Itália, onde existia um lobo muito feroz, estando sempre pronto a atacar uma vítima. A ameaça do lobo trazia muito pânico aos moradores.

Francisco ao chegar nesta cidade logo soube do pavor que a cercava, com sua forma calma e amorosa de ser, disse aos moradores que iria conversar com o lobo, e Francisco sai sozinho à procura do lobo. O lobo surge de maneira agressiva e rosnando, calmamente, Francisco começou a falar com o lobo, primeiramente parece que o lobo não está nenhum pouco interessado em escutar Francisco, porém continua até propor ao lobo: "Irmão lobo, tu fazes muitos danos nesta terra, e grandes malefícios, destruindo e matando as criaturas de Deus sem sua licença; e não somente mataste e devoraste os animais, mas tiveste o ânimo de matar os homens feitos à imagem de Deus; pela qual coisa és digno da forca, como ladrão e homicida péssimo: e toda a gente grita e murmura contra ti, e toda esta terra te é inimiga. Mas eu quero, irmão lobo, fazer a paz entre ti e eles; de modo que tu não mais os ofenderás e eles

\footnotetext{
${ }^{13}$ Números 6, 22:26.

${ }^{14}$ Mateus 26:52
} 


\section{http://ensaios.usf.edu.br/}

te perdoarão todas as passadas ofensas, e nem homens nem cães te perseguirão mais" O lobo então calmo com aquela proposta inclinou-se. Francisco continuou a falar: "Irmão lobo, desde que é de teu agrado fazer e conservar esta paz, prometo te dar continuamente o alimento enquanto viveres, pelos homens desta terra, para que não sofras fome; porque sei bem que pela fome é que fizeste tanto mal. Mas, por te conceder esta grande graça, quero, irmão lobo, que me prometas não lesar mais a nenhum homem, nem a nenhum animal: prometes-me isto?" Então, finalizou: "Irmão lobo, eu te ordeno em nome de Jesus Cristo que venhas agora comigo sem duvidar de nada, e vamos concluir esta paz em nome de Deus". E através dessa suplica o lobo conseguiu compreender suas palavras, ao retornarem à cidade, em frente a todas as pessoas o lobo ergueu a pata juntando-a nas mãos de Francisco, selando, dessa forma, o pacto de convivência pacífica.

Analisando esse pequeno trecho da vida de Francisco verifica-se a conduta pacífica e tranquila a ponto de dialogar com um lobo, é certo que esse diálogo aconteceu de maneira não verbal, através dos sentidos, a Paz estava tão impregnada em seu ser, que fora capaz de transmitir através de seu olhar, de sua postura ou até mesmo de sua simples presença. Um grande passo para o diálogo é deixar os julgamentos prematuros, pois grandes problemas podem surgir de ruídos da comunicação. Neste contexto, Paulo Freire define o diálogo como: um encontro dos homens para a tarefa comum de saber agir, se rompe, se seus polos (ou um deles) perdem a humildade. Como posso dialogar, se alieno a ignorância, isto é, se a vejo sempre no outro, nunca em mim? (FREIRE, 1987).

\subsection{O PAPEL DE FRANCISCO DE ASSIS NA V CRUZADA}

O clero na Idade Média estava diretamente envolvido com a sociedade, participando de forma direta e indireta em muitos dos abusos e erros. Francisco estava longe da ideologia eclesiástica do seu tempo, contudo nunca demonstrou estar em desacordo com o Papa ou com a hierarquia eclesial. Não criticava, nem reprimia quem agia de maneira oposta ao seu modo de entender, mas através de seu exemplo tentava demostrar que poderiam agir de maneira diferente.

No ano de 1215 a pedido do papa Inocêncio III que reunisse o Concilio de Latrão e se preparasse mais uma Cruzada entre 1215 e 1216. O papa Inocêncio III morre no ano de 1216, seu sucessor Honório III dá continuidade à batalha contra os muçulmanos. Em 1218, Honório III dá autorização para Francisco se dirigir até o acampamento dos cruzados, em Damieta. São Boaventura no capitulo IX, relata que durante a Quinta Cruzada Francisco de Assis no ano de 1219, dirigindo-se para Síria com a audácia de se fazer conduzir à presença do sultão Malik Al-Kamil, na tentativa de parar a guerra e as Cruzadas e de indicar que outras armas os homens tinham em relação às espadas, que consistia no encontro e a paz. Sem a violência dos cruzados com mansidão, tem objetivo de restituir a paz em uma guerra que fomentava ódio, e abandonar a visão de que os combatentes que aniquilavam mulçumanos tinham a glória no céu.

Le Goff relata como se deu tal empreitada:

Em 1219, entretanto, Francisco retoma seu velho desejo: ir aos infiéis, convertê-los ou sofrer martírio. Embarcando em Ancona a 24 de junho assistiu à tomada de Damieta pelos cruzados e 5 de novembro, desgostou-se com o comportamento cúpido e sanguinário dos cruzados, consegui uma entrevista com o sultão Malik AlKamil (LE GOFF, 2001, p.83). 


\section{http://ensaios.usf.edu.br/}

Ao se conduzir aos guardas sarracenos, assim que estes avistaram Francisco e seu confrade Irmão Iluminado, os muçulmanos os pegaram cruelmente e os açoitaram, batendo muito nos dois frades, até posteriormente conduzi-los ao acampamento. É valido lembrar que nesta época o sultão oferecia um bizâncio ${ }^{15}$ de ouro como recompensa para cada cabeça de cristão que lhe fosse apresentada.

Levado diante do sultão do Egito, Malik Al-Kamil, São Francisco pregou valentemente o cristianismo e ofereceu-se para entrar no ordálio ${ }^{16}$ de fogo juntamente com um sacerdote sarraceno, para assim provar ao sultão que a Lei de Cristo era verdadeira "Manda acender uma grande fornalha os teus sacerdotes e eu entraremos nela e, pelo que acontecer, poderás saber qual das duas religiões é a mais santa e mais verdadeira!", o sultão respondeu: Irmão, eu não creio que algum sacerdote sarraceno queira entrar no fogo por sua fé. "Então eu entrarei sozinho", respondeu Francisco. "Se eu morrer, atribuirás isso aos meus pecados; mas se o poder divino me proteger, juras reconhecer Cristo como verdadeiro Deus e Salvador?". E, nesse caso, o sultão deveria se fazer batizar com todo o seu povo, mas o sultão negou temendo a revolta de seu povo, porém admirava as virtudes de Francisco e o escutava com prazer.

Depois o Sultão o quis cumular de presentes, mas Francisco recusou todos. Amedrontado de que alguns dos de seu exército, pela eficácia da palavra de São Francisco, fossem convertidos, o sultão o fez conduzir, com as maiores atenções ao acampamento dos cruzados, recomendando: "Não te esqueças de mim nas tuas orações", disse-lhe ao despedirse, "e possa Deus revelar-me por tua intercessão a crença que lhe é mais agradável". Assim Francisco voltou ao campo cruzado, sendo-lhe permitido pregar por aquela região.

É muito proveitoso mencionar o comentário do Sr. Plinio Corrêa de Oliveira na Palestra "Santo do Dia" ministrada em 16 de novembro de 1972 aos membros e sócios da TFP, a respeito de tal episódio:

O mundo estava dividido em dois campos opostos. Essa divisão estava eriçada de espadas e lanças de ambos os lados. De um lado o mundo maometano, de outro lado o mundo católico. Nessa situação, uma expedição militar embarca cheia de ardor. Ela vai levando o homem que, para a sensibilidade deformada de nossos dias, é precisamente o contrário do espírito militar: São Francisco de Assis. O santo da doçura, da ternura, da bondade, que cantava aos passarinhos e chamava o boi e a vaca de irmãos; o santo da fraternidade, esse santo vai no meio dos cruzados, parece que seu contínuo cântico de afabilidade, cordialidade e amor é o contrário da mensagem dos cruzados. Ele tem esperança de converter o sultão[...]. Dir-se-ia então que São Francisco de Assis ia como companheiro dos cruzados, com o intuito de tornar inútil a Cruzada[..]E aí uma das enormes antíteses, não só daquele tempo, mas de todos os tempos, se estabelece: o diálogo de São Francisco com o sultão. Fala-se hoje tanto em diálogo. Isso foi diálogo! (OLIVEIRA, 1972).

\footnotetext{
15 A moedagem bizantina, Bizâncio uma das mais poderosas cidades da Antiguidade, foi fundada em 675 a.C. pelos habitantes da cidade grega de Megara. A cidade tornou-se muito poderosa graças ao intenso comércio e à sua estratégia posição geográfica, no estreito que une o mar Egeu ao mar negro, a Europa e a Ásia. A denominação de Constantinopla, séculos mais tarde da sua fundação, foi dada pelo imperador Constantino, que em 326 fez de Bizâncio a nova capital do Império Romano. Diferentemente da moedagem romana, da qual derivou, a moedagem bizantina apresenta uma iconografia (descrição e/ou representação de imagens) todo particular, menos realística e expressiva, mas ainda assim cheia de fascínio e mistério.

${ }^{16}$ Ordálio (Mubahâla), era uma fogueira feita em público para que por entre chamas, fogo e brasas, numa prova de coragem e fé, as pessoas a atravessassem incólumes.
} 


\section{http://ensaios.usf.edu.br/}

Naquele momento enquanto a Igreja pregava as cruzadas, Francisco ia ao encontro dos muçulmanos, considerando-os seus irmãos, mostrando, a quem até então só tinha conhecido a violência dos cristãos, a mansidão do Evangelho e a mensagem de paz. São Francisco se dirige ao Egito não por amor aos cristãos mas por amor aos mulçumanos, daí se vê seu grande ardor ecumênico.

Francisco deixa recomendado aos seus confrades como devem se portar em meio aos mulçumanos, na regra Não-Bulada ${ }^{17}$ explica aos frades como deviam conviver entre os muçulmanos:

Se, pois, houver irmãos que quiserem ir para entre os sarracenos e outros infiéis, que vão com a licença de seu ministro e servo[...]. E os irmãos que partirem poderão proceder de duas maneiras espiritualmente com os infiéis: primeiro modo consiste em absterem-se de rixas e disputas, submetendo-se "a todos os homens por causa do Senhor" e confessando serem cristãos (RnB, capítulo XVI).

Assim sem brigas ou disputas, era a convivência dos franciscanos, devendo falar de Deus somente em situação de respeito mútuo, caso contrário deviam através de seu bom exemplo ensinar a vivência do evangelho. De tal modo em meio à guerra, Francisco se conduziu aos mulçumanos para apresentar e viver a paz, como grande mediador.

\subsection{FRANCISCO DE ASSIS E A COMUNICAÇÃO NÃO VIOLENTA}

Criar uma atmosfera favorável ao diálogo é um grande passo para facilitar possíveis acordos integrativos. Basicamente é o processo de levar os negociadores a aceitarem a mediação, a confiarem no mediador e no processo de mediação. De maneira equilibrada, deve intervir no sentido de melhorar o relacionamento entre as partes, assim como utilizar uma comunicação não violenta, desenvolvendo soluções integrativas. Dentro desta inclusão, o papel do advogado é fundamental na Negociação, primordialmente deve se abandonar a ideia de uma ideologia competitiva e de ganhar da outra parte, e passar do cuidar do cliente para cuidar das relações e do acordo, agindo de maneira para pacificar as relações, tendo desta forma uma postura colaborativa, e não propícia à lide. Para se assumir um pensamento propício à negociação, deve-se primeiro abandonar a ideia de ganhar da outra parte, contribuindo para a pacificação do conflito.

A comunicação não violenta é a atitude de se dirigir aos outros de maneira afável, ser magnânimo capaz de criar um ambiente de paz. Marshall Rosenberg em seu livro "Comunicação não violenta" apresenta técnica para se relacionar com outros, mais primeiramente com si mesmo, que inclui grandes requisitos da mediação, como a empatia e a escuta ativa, abandonando os pré-julgamentos e estando disposto a estar ali verdadeiramente.

Assim Marshall Rosenberg diz "Não pense que o que diz é empatia. Assim que pensa que o que diz é empatia, estamos distantes do objetivo. Empatia é onde conectamos nossa atenção, nossa consciência, não o que falamos (ROSENBERG, 2006, p.156)" e conceitua mais profundamente uma postura empática como sendo:

A empatia é a compreensão respeitosa do que os outros estão vivendo. O filósofo chinês Chuang-Tzu afirmou que a verdadeira empatia requer que se escute com todo o ser: "Ouvir somente com os ouvidos é uma coisa. Ouvir com o intelecto é outra. Mas ouvir com a alma não se limita a um único sentido - o ouvido ou a mente, por

\footnotetext{
${ }^{17}$ Regra não aprovada, ou seja, a que não recebeu a bula de chumbo, o selo papal de aprovação.
} 


\section{http://ensaios.usf.edu.br/}

exemplo. Portanto, ele exige o esvaziamento de todos os sentidos. E, quando os sentidos estão vazios, então todo o ser escuta. Então, ocorre uma compreensão direta do que está ali mesmo diante de você que não pode nunca ser ouvida com os ouvidos ou compreendida com a mente (ROSENBERG, 2006, p.156).

Assim sendo, a comunicação não violenta colabora para nos fazer refletir a maneira que estamos nos expressando ou escutando o outro. Tendo consciência de fato da mensagem que queremos transmitir. O Professor Jean Marie Muller fundador e diretor do Instituto de Pesquisa sobre a Resolução não violenta de Conflitos na França e em seu Livro "O princípio da não violência" disserta a respeito de tal seguimento:

A paz não é não pode ser e nunca será a ausência de conflitos, mas sim o controle, a gestão e a resolução dos conflitos por outros meios que não os da violência destruidora e mortal [...] A não violência não pressupõe, portanto, um mundo sem conflitos. Não tem como projeto político construir uma sociedade em que as relações entre os homens estejam alicerçadas unicamente na confiança, visto que esta só pode ser estabelecida através das relações de proximidade, só pode ser efetivada na relação com o próximo (MULLER, 2007, p. 20).

Através da Comunicação não Violenta será capaz de observar os comportamentos e as condições que estão afetando as partes. Aprendendo a identificar e articular claramente o que de fato desejamos em determinada situação. Na comunicação não violenta os velhos hábitos devem ser substituídos, como atacar ou se recuar quando esta sendo criticado ou julgado, a postura violenta vai sendo substituída.

A escuta ativa exerce um papel importante neste ponto. Nos dias atuais a humanidade tem uma desesperada necessidade de diálogo, e através da escuta ativa será possível perceber, qual o verdadeiro motivo do conflito, sendo assim um bom comunicador é aquele que sabe escutar.

Porém, o escutar não é uma tarefa fácil como lembra Rubem Alves:

Sempre vejo anunciados cursos de oratória. Nunca vi anunciado curso de escutatória. Todo mundo quer aprender a falar. Ninguém quer aprender a ouvir. Pensei em oferecer um curso de escutatória. Mas acho que ninguém vai se matricular. Escutar é complicado e sutil (ALVES, 1933, p. 65).

Através da escuta ativa deve ser demonstrada a empatia, uma escuta interessada, demostrando estar atendo ao que está sendo dito, não sendo algo fingido ou forçado, mas gratuito, com qualidade da presença. Já dizia Jiddu Krishnamurti que "A forma mais elevada da inteligência humana é a capacidade de observar sem julgar", e assim se começa um grande passo para uma boa mediação, a capacidade de sair de um sistema de valores, crenças, princípios e adentrar na realidade do outro. Como ensina Thomas Gordon estar despido de sentimentos, e disponível ao outro "como ele é" e não "como o vejo" ou "como gostaria que ele fosse" evitando o julgamento de valores.

Uma escuta ativa é escutar pacientemente sem interromper, direcionando atenção sem criticar ou demonstrar desinteresse, principalmente através da postura na qualidade de escuta, que diz muito mais do que as palavras. $\mathrm{O}$ mediado deve estar atento, para colaborar para a atmosfera de conciliação (ALMEIDA, 2012, p 318).

Ao ser interrogado pelo sultão em nome de quem Francisco falava de pronto respondeu: "da parte de Deus venho mostrar ao vosso povo o caminho da salvação, e anunciar o evangelho de Nosso Senhor Jesus Cristo, ali mesmo pôs a falar sobre a Santíssima 


\section{http://ensaios.usf.edu.br/}

Trindade, e permaneceu por alguns dias o sultão o ouvia com muito agrado". Assim se dá o início ao diálogo entre eles, um diálogo inter-religioso, mesmo entre as diferenças. Tal atitude só é possível porque o Sultão foi capaz de escutar Francisco e permitiu ter uma percepção diferente da própria, admitindo que pudesse existir uma verdade além da que conhecia e acreditava ser legítima, ou seja, foi capaz de ouvir.

\subsection{FRANCISCO DE ASSIS E A COMUNICAÇÃO NÃO VERBAL}

Partindo do pensamento de que tudo é comunicação, e que essa é a mais básica e vital de todas as necessidades humanas, depois da sobrevivência física, e que todo o comportamento pode ser entendido como uma mensagem de comunicação, mesmo que não seja verbalmente, mas principalmente pelo comportamento. Podemos dizer que a comunicação humana não está resumida somente a palavras, mas os gestos e expressões completam a comunicação e as tornam mais compreensíveis e eficazes, sendo muitas vezes mais esclarecedoras do que as próprias palavras.

Desta forma as falhas na comunicação de forma geral, podem ocorrer por falta de percepção ou mesmo ruídos ao se comunicar, a compreensão da fala é uma parte do processo comunicativo. A Comunicação não verbal refere-se às maneiras de expressão que não utilizam palavras ou escrita, e engloba o aprendizado dentro de uma cultura, gestos, expressões faciais, postura corporal, o tom de voz e até mesmo a vestimenta que estamos usando.

As pesquisas científicas atuais evidenciam que o uso adequado é tão ou mais importante de que o domínio da linguagem verbal, compreendendo que expressões e manifestações corporais são elementos essenciais. Charles Darwin ${ }^{18}$ na obra "The Expression of The Emotions in Man and Animals"19, estudou os princípios gerais da comunicação dos animais e dos homens, com o propósito de pesquisar se as mesmas expressões e gestos tem o mesmo significado. A visão de Francisco de Assis não foge disso, pois não se relacionava com as criaturas como sendo ser superior, mais sim se sentia parte da criação, como mera criatura, deste modo era capaz de se comunicar com os demais seres, Francisco se mostrava um humano ecológico. Através da compaixão, Francisco é capaz de se comunicar com todos, sejam humanos, pássaros, animais silvestres, todos entendem a linguagem do coração, sendo capaz de se confraternizar com tudo e com todos.

Marshall B. Rosenberg aborda em um de seus capítulos justamente sobre esta forma de comunicação que nos leva a nos entregarmos de coração, citando:

O que eu quero em minha vida é compaixão, um fluxo entre mim mesmo e os outros com base numa entrega mútua, do fundo do coração[...] ]acredito que é de nossa natureza gostar de dar e receber de forma compassiva. Assim, durante a maior parte da vida, tenho me preocupado com duas questões: o que acontece que nos desliga de nossa natureza compassiva, levando-nos a nos comportarmos de maneira violenta e baseada na exploração das outras pessoas? E, inversamente, o que permite que algumas pessoas permaneçam ligadas à sua natureza compassiva mesmo nas circunstâncias mais penosas? (ROSENBERG, 2006, p. 22).

\footnotetext{
${ }^{18}$ Nasceu em 1809, na Inglaterra, de uma família de médicos renomados. Frequentou as universidades de Edimburgo e Cambridge, mas se destacou pouco. Em 1831, graças à influência familiar, embarcou como naturalista a bordo do HMS Beagle. A viagem de cinco anos pela América do Sul e ilhas Galápagos mudaria sua vida e a história da biologia. Ao voltar, instalou-se num vilarejo próximo a Londres, produzindo ali sua rica e extensa obra científica. Morreu em 1882, aos 72 anos, e foi sepultado na abadia de Westminster.

${ }^{19}$ Tradução: A Expressão das Emoções no Homem e nos Animais.
} 


\section{http://ensaios.usf.edu.br/}

O mediador deve ser aquele capaz de perceber o que ainda não foi dito, justamente isso que aproxima Francisco do perfil de mediador sua capacidade de ver luz onde só há trevas. Por fim, Francisco de Assis é perfeito entendedor da comunicação não verbal, uma grande prova disso é frase dita por ele: "Evangelize sempre, se necessário use palavras". Para Francisco a linguem do coração era sim a mais importante, de forma geral, damos maior importância às palavras expressas, no entanto, existem outras dimensões comunicativas que são importantes para a compreensão e interação.

\subsection{A NEGOCIAÇÃO E O ACORDO}

A primeira sessão é o marco inicial da mediação, inaugurando o processo de diálogo e negociações entre as partes, partindo do pressuposto que só se chega a um acordo quando as partes estão dispostas a uma negociação, mesmo que implicitamente, o mediador através do diálogo deve buscar critérios para se chegar a uma solução satisfativa para as partes, pois o conflito ocorre justamente quando duas ou mais pessoas tem interesses incompatíveis. $\mathrm{O}$ primeiro passo para o acordo é pontuar as opções possíveis para solução do problema, devido às emoções estarem geralmente acentuadas tende-se a ver o outro como parte do problema e não como membro em uma negociação na qual deve-se buscar a colaboração mútua, afastando as pessoas envolvidas do problema.

É essencial dentro da mediação uma boa negociação e consequentemente um bom acordo e a figura do mediador, visto que o mesmo age como mestre ${ }^{20}$, contudo não mestre no sentido de estar em uma posição superior, mas no sentido de maestria, de saber administrar a grande arte de se comunicar e de se relacionar, pois se de fato a comunicação fosse algo fácil, não haveria tantos conflitos.

Francisco de Assis compreendia muito bem esta arte, São Boaventura narra o seguinte:

Francisco lhe anunciou o Evangelho de Cristo; o Espírito Santo e o poder de Deus lhe comunicavam tal força de persuasão, que o Sultão ficou maravilhado. Deus abrandou seu coração e ele ouviu o santo com benevolência. Ao encontrar em Francisco um coração ardente, força de ânimo, desprezo da vida, eloquência tão persuasiva, o Sultão teve por ele uma grande afeição e devoção. Tratou-o com muita deferência, ofereceu-lhe ricos presentes e insistiu que permanecesse com ele (LM, capitulo III).

O interesse maior de Francisco ia em desacordo com a igreja da época que visava conquistar em nome de Deus a terra santa, através de guerras e aniquilar também fisicamente os muçulmanos. Francisco ao contrário pensava que deviam viver entre os muçulmanos pacificamente, postura oposta a do uso da violência, buscou a negociação entre os seus adversários, sabia que "a humildade é a chave que abre todas as portas" e por se apresentar ao sultão de maneira sutil e humilde foi possível haver um diálogo entre eles, e se acordarem. Infelizmente não houve o fim da cruzada como era desejado por Francisco, pois também os cruzados teriam que ceder, o que não ocorreu mesmo com aconselhamento e a previsão de um futuro fracasso, que de fato viera a ocorrer ${ }^{21}$.

\footnotetext{
${ }^{20}$ Mestre do latim magister-tri, "o que manda, dirige, ordena, guia, conduz, diretor, inspetor, administrador, o que ensina".

${ }^{21}$ No Segundo Livro de São Tomaz de Celano no Capitulo IV se Conta: Quando o exército dos cristãos assediava Damieta, estava presente o Santo com alguns companheiros. Anseios de martírio os tinham levado até
} 


\section{http://ensaios.usf.edu.br/}

O acordo é uma expressão que significa que existe concordância, que todos os lados envolvidos concordam, estão de acordo quando conseguem conciliar suas opiniões. Pode-se concluir, portanto que o maior acordo que houve entre Francisco e o Sultão Malik Al-Kamil, foi o de serem capazes de viver o shalom ${ }^{22}$, ou seja, viver em Paz, a Aliança ${ }^{23}$ de viver e se deixar viver. Este viver em paz não quer dizer que não haja conflitos, mas pelo respeito mútuo de serem capazes de ter um bom relacionamento, eliminando os preconceitos que ocorrem pelas diferenças.

Zehr em seu livro "Trocando as lentes" traz um conceito a palavra shalom:

A tradução corriqueira de shalom, "paz", transmite um aspecto do conceito, mas não expressa adequadamente todas as conotações da palavra. Shalom diz respeito a uma condição em que "tudo está certo" e as coisas estão como devem ser em inúmeras dimensões (ZEHR, 2008, p.65).

Deste modo o "Shalom" de Francisco de Assis só pode se realizar, pois mesmo em meios aos erros, e inúmeras diferenças com sultão deseja-lhe bem-estar, o quis bem, o foi capaz de fazer com que aquele sanguinário sultão, que exterminava inúmeros cristãos também o quisesse bem a ponto de convidá-lo a morar em seu palácio. Um dos maiores reflexos deste acordo de paz e convivência pacífica entre franciscanos no meio povo do Oriente, resultou na Custódia dos Lugares Santos a Ordem dos Frades Menores, os franciscanos, continuaram a fazer e o que o fundador lhe ensinara com seu exemplo.

\section{CONSIDERAÇÕES FINAIS}

No presente artigo podemos notar que o conceito de paz na Idade Média, com base na experiência de Francisco de Assis é a de uma sociedade que garanta segurança, e a construção e manutenção de relações pacíficas, como forma elementar para organizar e conservar a vida em sociedade. Neste sentido, a paz significa a satisfação das necessidades fundamentais dentro de uma comunidade, na qual a justiça e a paz se unem para garantir que todos os seres humanos tenham acesso aos meios para o atendimento de suas necessidades fundamentais.

\footnotetext{
ali, depois de cruzarem o mar. Um dia, tendo sabido que os nossos soldados se preparavam para travar batalha, entristeceu-se grandemente e, dirigindo-se aos companheiros, disse-lhes: O Senhor deu-me a saber que, se a batalha se travar hoje, será um desastre para os cristãos. Se lhes digo isto, hão-de tomar-me por louco; se me calo, há-de remorder-me a consciência. Que pensais? Pai - respondeu o companheiro - não te importes com o juízo dos homens; de resto, não é de hoje pensarem isso de ti. Descarrega a tua consciência e teme antes a Deus que aos homens! Imediatamente correu o Santo ao encontro dos cristãos e, para bem deles, tentou dissuadi-los da batalha, anunciando-lhes a derrota. Eles, contudo, tomando por brincadeira o que era funesta verdade, endureceram o coração e não quiseram saber do aviso. Lançados ao assalto, travam combate e lutam corpo a corpo com o inimigo. Durante o combate, angustiado, Francisco pede ao companheiro que se levante e vá perscrutar o horizonte. Mas como nada descortina, nem dessa vez, nem de uma segunda, manda-o uma terceira. E o que então vê é o exército cristão em debandada, terminando em vergonha o que antes se lhes afigurava triunfo garantido. Foi tal o desastre, que o exército perdeu seis mil homens, entre mortos e prisioneiros. Confrangeu-se o Santo com tão triste sorte, e eles não menos, arrependidos de o não terem ouvido.

22 Shalom consiste na palavra hebraica shalom (em grego, usado no Novo Testamento, o vocábulo correspondente é eirene). Semelhante a shalom, eirene se refere à paz entre os povos e Deus, e entre as pessoas em várias instâncias.

${ }^{23}$ Aliança o conceito de aliança é a base e modelo primário de shalom na Bíblia. No contexto bíblico uma aliança é um acordo com força de lei entre as partes. A aliança presume um relacionamento pessoal entre elas e implica em responsabilidades e compromissos recíprocos.
} 


\section{http://ensaios.usf.edu.br/}

Nesta ótica, nos deparamos com a figura do mediador sendo aquele capaz de solucionar os conflitos em que as partes muitas vezes estão esgotadas, não tendo a capacidade de dialogar pacificamente. Como descrito da experiência jurídica medieval, os conflitos já eram eminentes, da qual nasce a importância da cultura de paz, que em certos momentos foi essencial para resolução de conflitos através das técnicas que foram incorporadas durante a vida São Francisco de Assis. Francisco assume uma postura de reconciliador procurando evitar combates. O Sultão Malik Al-Kamil conheceu em Francisco um homem cortês e não um inimigo, o Sultão não se converteu ao cristianismo, mas eles foram capazes de alçar algo imaginável na presente situação, ganhando respeito e aprenderam um com o outro, foi o encontro com respeito à diversidade, no diálogo cortês, no amor gratuito.

Dentre as qualidades de Francisco de Assis, atribuir a ele o título de pacificador se mostra muito apropriado com a vida que levava, e como demostrado no teor do presente artigo. Em uma análise sucinta de sua vida, vemos um ser humano que veio ao mundo para trazer o conceito da paz, e com sua magnanimidade ajudava as pessoas desinteressadamente, colocava-se a disposição dos outros sem julgamentos preliminares, agia com nobreza, era bondoso e dadivoso. Tais virtudes sempre se mostraram ao longo da vida de Francisco por tal motivo podemos mencioná-lo como modelo para nos tornarmos grandes agentes da paz.

Não se pode negar que o objetivo principal ao acionar o judiciário é a resolução do conflito, mas infelizmente a sociedade atual apresenta cada vez conflitos mais complexos. Desta forma, a pretensão principal foi demonstrar que o acordo não é de fato o mais importante, mas sim a capacidade de conviver pacificamente, construindo uma sociedade em que as pessoas, através do diálogo, resolvam seus conflitos, sendo elas autônomas em suas vontades, e não dependendo do Estado e da jurisdição estatal para solucionar questões que possam se resolver através da comunicação, de modo a abandonar uma cultura demandista e adversarial.

Dentro de tais aspectos, a mediação se mostra como instrumento mais adequado para que se chegue à cultura da paz, pois é não somente uma modificação de um processo, mas sim a ampliação de uma visão de sociedade, que estimula os adeptos dessa postura a difundir a paz e a solução pacífica dos conflitos.

\section{REFERÊNCIAS}

AUGRAS, Monique. "Uma entrevista com Jacques Le Goff”. In: Revista Estudos Históricos, Rio de Janeiro, v. 4, n. 8, p. 262-270, dez. 1991. ISSN 2178-1494. Disponível em: <http://bibliotecadigital.fgv.br/ojs/index.php/reh/article/view/2317/1456>. Acesso em: 22 abril. 2017.

AGUIAR, Porfirio. Vida de São Francisco de Assis. São Paulo: Sem Editora, 1925.

ALVES, Rubem. O amor que Acende a Lua, Campinas: Editora Papirus, 1999.

BACELLAR, Roberto Portugal, Mediação e Arbitragem (Coleção saberes do direito; 53). São Paulo, Editora Saraiva, 2012.

BURKE, Peter. A Revolução Francesa da historiografia: a Escola dos Annales 1929-1989. Tradução de Nilo Odália. São Paulo: Editora Universidade Estadual Paulista, 1991. 


\section{http://ensaios.usf.edu.br/}

A Invenção da Biografia e o Individualismo Renascentista. Tradução José Augusto Drummond. 1997.

Disponível em: <http://bibliotecadigital.fgv.br/ojs/index.php/reh/article/view/2038/1177> . Acesso em: 18 abr. 2017.

CELANO, Tomás de. Primeira vida de São Francisco. Disponível em: <http://www.franciscanos.org.br/?page_id=3235>. Acesso em 19 dez. 2017.

DARWIN, Charles. A Expressão das Emoções no Homem e nos Animais. São Paulo: Editora Companhia de Bolso, 2009.

FREIRE, Paulo. Pedagogia do Oprimido. 17ª ed. Rio de Janeiro: Editora Paz e Terra, 1987.

FISHER, Roger; PATTON, Bruce; URY, William. Como Chegar ao Sim: A Negociação de Acordos Sem Concessões. $3^{\text {a }}$ ed. Rio de Janeiro: Editora Solomon, 2014.

GROSSI, Paolo. A Ordem Jurídica Medieval. Tradução de Denise Rossato Agostinetti. São Paulo: Editora WMF Martins Fontes, 2014.

História da propriedade e outros ensaios. Tradução de Luiz Ernani Fritoli e Ricardo Marcelo Fonseca. Rio de Janeiro: Editora Renovar, 2006.

O Direito entre Poder e Ordenamento. Tradução de Arno Dal Ri Júnior. Belo Horizonte: Editora Del Rey, 2010.

KAZANTZAKIS, Nikos. O Pobre de Deus. São Paulo: Editora Círculo do Livro, 1974.

LE GOFF, Jacques. São Francisco de Assis. $4^{\text {a }}$ ed. Rio de Janeiro: Editora Record, 2001.

São Luís. Tradução de Marcos de Castro. Rio de Janeiro: Editora Record, 1999.

MAZZUCO, Vitório, Francisco de Assis e o Modelo de amor Cortês Cavaleiresco, Rio de Janeiro: Editora Vozes, 2001.

SANTOS, João Vitor. Uma outra face de Francisco de Assis: Entrevista especial com Chiara Frugoni. 2015. Disponível em: <http://www.ihu.unisinos.br/entrevistas/544964-aoutra-face-de-sao-francisco-de-assis->. Acesso em: 01 abr. 2017.

SENNA, Sergio. O que é Comunicação Não Verbal?. Disponível em: <https://ibralc.com.br/comunicacao-nao-verbal/>. Acesso em: 01 abr. 2017.

PROVÍNCIA FRANCISCANA DA IMACULADA CONCEIÇÃO DO BRASIL. São Boaventura: o grande doutor franciscano. 2017. Disponível em: <http://www.franciscanos.org.br/?p=59356>. Acesso em: 01 abr. 2017.

MIRANDA, Maria Bernadete. "Aspectos relevantes do instituto da mediação no mundo e no Brasil". In: Revista Virtual Direito Brasil, v. 6, n. 2 de 2012. Disponível em: 


\section{http://ensaios.usf.edu.br/}

http://www.direitobrasil.adv.br/arquivospdf/revista/revistav62/artigos/be2.pdf. Acesso em: 01 abr. 2017.

MOREIRA, Alberto da Silva. São Francisco e as Fontes Franciscanas. Bragança Paulista: Editora Universitária São Francisco - IFAN, 2017.

MUlleR, Jean Marie. O Princípio da Não Violência: Uma Trajetória Filosófica. Tradução de Inês Polegato. São Paulo: Palas Athena, 2007.

NASCIMENTO, Douglas da Veiga. Aspirações e Vertigens na Marcha do Intelecto: Os Bacharéis e a Formação da Cultura Urbana na Cidade de Curitiba (1870-1883). 2012. Disponível em: <http://acervodigital.ufpr.br/handle/1884/27652>. Acesso em: 01 abr. 2017.

NUNES, Antônio Carlos Ozório, Manual de Mediação: Guia Prático da Autocomposição. São Paulo: Editora Revista dos Tribunais, 2016.

OLIVEIRA, Plínio Corrêa. Les Templiers. São Paulo, 1972. Palestra "Santo do Dia" ministrada em 16 novembro de 1972 aos membros e sócios da TFP.

PAZZELLI, Raffaele. São Francisco e a Ordem Terceira. Santo André: Editora Mensageiro de Santo Antônio, 2009.

PINTARELLI, Frei Ary E. Cavaleiros de Dona Pobreza, Petrópolis: Editora Vozes, 1997.

ROSENBERG, Marshall B. Comunicação Não-Violenta: Técnicas Para Aprimorar Relacionamentos Pessoais e Profissionais. Tradução Mário Vilela. São Paulo: Editora Ágora, 2006.

SALES, Fernando Augusto De Vita Borges de. Novo Código de Processo Civil Comentado: $1^{\circ}$ volume (artigos $1^{\circ}$ a 1.072). $1^{a}$ ed. São Paulo: Editora Rideel, 2016. v. 1. ISBN 978-85339-3813-7.

SCHWERZ, Frei Nestor Inácio. "A Mística da Paz em Francisco e Clara". In: Revista Franciscana, volume IV, 2004. Disponível em: 〈http://www.franciscanos.org.br/?p=24384>. Acesso em: 01 abr. 2017.

SILVA, S. C. O historiador e as biografias: desafios, possibilidades e abordagens de trabalho. Revista História, Imagem e Narrativas, 2012. Disponível em:<www.historiaimagem.com.br/edicao14abril2012 /biografias.pdf >. Acesso em: 14 maio. 2017

TEIXEIRA, Frei Celso Márcio. Escritos de São Francisco. $4^{a}$ ed. Petrópolis: Editora Vozes e FFB, 2013.

Fontes Franciscanas e Clarianas. Petrópolis: Editora Vozes e FFB, 2008. 


\section{http://ensaios.usf.edu.br/}

WATANABE, Kazuo. "Cultura da Sentença e Cultura da Pacificação". In: Estudos em Homenagem à Professora Ada Pellegrini Grinover (org. Flávio Luiz Yarchell e Maurício Zanoide de Moraes). São Paulo: DPJ, 2005.

WEIL, Pierre; TOMPAKON, Roland. O Corpo Fala. 52 a ed. Rio de Janeiro: Editora Vozes, 2001.

ZEHR, Howard. Trocando as Lentes: Um Novo Foco Sobre o Crime e a Justiça. Tradução Tônia Van Acker. São Paulo: Editora Palas Athena, 2008.

Aceito em: 02/08/2018.

Publicado em: 10/12/2018. 